\title{
JUDECĂTORUL ȘI FABULISTUL ORHEIAN ALECU DONICI, PRECURSOR AL ETNOLOGIEI JURIDICE ROMÂNEȘTI
}

Scriptural support of the communication drafted for the International Scientific Conference, dedicated to the Centenary of the Great Union with the generic "Return of Bessarabia in the Romanian legal space", which took place at the Public University of Chișinau, from March 22-23, 2018. In order to mitigate symbolically from the minor premises regarding the recent evolutions of the Romanian legal ethnology and anthropology part of this material was also adapted for the annual Conference, within the series of conferences of the Robertianum Centre for European Private Law, under the aegis of "Law and Literature" from the spring of 2019. I hope for these small efforts to become a palladium that could catalyse a fruitful starting point for shaping the foundations of the legal sciences as natural, living, real elements that mark the moral and justice spirit of the Romanian people and European legal culture. The conference held in this framework was entitled as follows: Etnografia, fabulistica și etnologia juridică - albia ce unește două maluri în An Centenar 1918-2018. Valori juridico-morale perene versus quasi-efemeride sau scoica Arctica Islandica (40o ani) versus efemerida libelulă (Anisoptera de o zi) ... (Ethnography, fabulistics and legal ethnology - the river bed that unites two banks in the Centenary Year 1918-2018. Perennial juridical-moral values versus quasi-

* Prof., Facultatea de Drept, Universitatea „Alexandru Ioan Cuza” din Iași, fost judecător la CJUE, fondator al Centrului „Robertianum” de Drept privat la UAIC Iași, mailto:valerius m ciuca@yahoo.com. 
ephemerides or Arctic Iceland shells (40o years) versus dragonfly ephemerid (Oneday Anisoptera) ...

Dedicated to the memory of Professor Vladimir Hanga from Cluj, a Moldovan who ennobled the intellectual spirit of Transylvania, crossing the Carpathians, as in the Forty-Eighter Era, a Bessarabian ennobled the Moldovan spirit passing another internal border of the Reunited, rounded Romania ("România dodoloață"), the impetuous Prut river...

Motto: Non solum juris, sed bonarum etiam artium studijsque vacandum est. Principes mortales, res publica aeterna (Ovidius, Metamorphosis \& Tacitus, Annales) ${ }^{I}$

Rezumat: Paul Valéry a spus despre fabulă: „Încetul cu încetul, cei care au iubit-o sau au plăcut-o, cei care au putut măcar să o înțeleagă au dispărut. Cei care au cerut-o, cei care au stricat-o. cei care au luat-o în glumă, au murit și ei ... În curând, un instrument de plăcere și emoție va deveni un accesoriu școlar; ceea ce obișnuia să constituie adevărul, ceea ce obișnuia să constituie frumusețea se transformă într-un mijloc de constrângere sau într-un obiect care stârnește curiozitatea, însă o curiozitate care se fortează să fie curioasă. " („Oraison funèbre d'une fable", în Variétés, apud Sanda Radian, Măștile fabulei. Etape de evoluție în literatura română (The Fable Masks. Stages of Evolution in Romanian Literature), Editura Minerva, București, 1983, p. 5)

Într-o conferință recentă, desfășurată la Suceava, am exprimat unele regrete în legătură cu absența preocupărilor științifice în domeniul vast și important al etnografiei și etnologiei juridice din România, după cum urmează: „Etnografia și etnologia juridică nu sunt evident, în special, tratate în lucrarea grandioasă a lui Simeon Florea Marian. Știința era în curs de formare; nu era momentul dezvoltărilor particulariste. Mult mai târziu, prin intermediul unei alte lucrări de pionierat, cea a savantului și antropologului român Romulus Vulcănescu, au apărut câteva semne de îngrijorare pentru juriștii noștri, pentru sociologii de drept și antropologi, ce au început să se reflecte în cultura juridică românească. Până și marele etnograf Petru Ursache a recunoscut în creația sa etnografică, că domeniul era tratat deficitar.

\footnotetext{
1 "It is necessary not only to study law, but also the arts", Ioan Inocentiu Micu-Klein, Carte de înțelepciune latină. Illustrium poetarum flores. Florile poeților iluștri (Latin wisdom book. Illustrium poetarum flores. The Flowers of the Illustrious Poets), Edition by Florea Firan and Bogdan Hâncu, Editura Științifică, Bucharest, 1992, pp. 100-101, paraphrase to the lines of poet Publius Ovidius Naso: "Disce bonas artes moneo, Romana juventus / Non tantum trepidos ut tueare reos ("Young Romanians, I urge you to learn the beautiful speech as well, / Not just to know how to defend a fearful defendant." (Metamorphosis, 1.6)..
} 
În ceea ce privește fabula, aparent un gen literar minor, atât de mult lamentat, așa cum am văzut mai sus, de Paul Valéry, ca obiect de contemplare istorică, numai intersecția culturii juridice cu spiritul sapiential, moral și literar al poporului o crește considerabil; atât de mult încât devine un reper științific valoros în etnologia juridică emergentă înfrățită cu sociologia juridică, cu antropologia juridică și cu folclorul juridic. La modul cel mai serios, chiar dacă, nu-i așa, cu arme hilare și caricaturizante, cu un spirit jucăuș și deștept, fabula decriptează înclinația poporului pentru adevăr și dreptate sau, dimpotrivă, pentru fatalism gregar în raport cu viciile care corup națiunea psihologic și moral, rolul său este didactic. Tinerii juriști ar deveni nobilizați științific și cultural dacă ar prelua jurisprudența, „cazurile”, din fabule ... Sau dacă, maeștrii lor i-ar îndruma spre asocierea jurisprudenței cu spiritul comic și fabulos al judecătorului înțelept ...

Cuvinte cheie: Etnologie juridică, fabulă, morală judiciară, înclinație pentru justiție, morală publică, decădere legală și morală, judecător Alecu Donici, fabulist Alecu Donici.

\title{
THE JUDGE AND FABULIST FROM ORHEI, ALECU DONICI, A PRECURSOR OF ROMANIAN LEGAL ETHNOLOGY
}

\begin{abstract}
Paul Valéry said about fables as follows: "Little by little those who loved or liked it, those who were able to understand it disappear. Those who demanded it, those who broke it, those who bantered it died too ... Soon, an instrument of pleasure and emotion will become a school accessory; what used to constitute the truth, what used to constitute the beauty turns into a means of constraint or into an object that arouses curiosity, but a curiosity which forces itself to be curious." ("Oraison funèbre d'une fable", in Variétés, apud Sanda Radian, Măștile fabulei. Etape de evoluție în literatura română (The Fable Masks. Stages of Evolution in Romanian Literature), Minerva Publishing House, Bucharest, 1983, p. 5)

In a recent conference, held in Suceava ${ }^{2}$, I expressed some regrets in relation to the absence of scientific concerns in the vast and important field of legal
\end{abstract}

${ }^{2}$ Pagini de etnografie juridico-morală în opera fondatoare a bucovineanului polimat Simeon
Florea Marian, cronicar al sufletelor românești în pragul Marii Uniri. Remarcabila lui
contribuție la înfăptuirea milenarului ideal (Pages of legal-moral ethnography in the founding
work of the polymath from Bucovina Simeon Florea Marian, chronicler of Romanian souls on 
ethnography and ethnology in Romania, as follows: "Legal ethnography and ethnology are not obviously, in particular, delimited in Simeon Florea Marian's grandiose work. General science was in the course of being established; it was not the time for particularistic developments. It was late when by means of another pioneering work, that of the Romanian scholar and anthropologist Romulus Vulcănescu, some issues of concern for our jurists, for law sociologists and anthropologists started to be reflected in the Romanian legal culture. Very few. Even the great ethnologist Petru Ursache acknowledged that the domain was deficient, in his very impressive creation of ethnosophy".

As for the fable, apparently a minor literary genre, so much lamented, as we have seen above, by Paul Valéry, as an object of historical contemplation only, the intersection of the legal culture with the sapiential, moral and literary spirit of the people increases considerably; so much that it becomes a valuable scientific landmark in the emergent legal ethnology twinned with legal sociology, with legal anthropology and with legal folklore ${ }^{3}$. In the most serious way, even if, isn't it true, with hilarious and caricaturizing weapons, with a playful and clever spirit, the fable decrypts a people's propensity for truth and justice or, conversely, for gregarious fatalism in relation to the vices that corrupt the nation psychologically and morally. Its role is didactic. The young jurists would become scientifically and culturally ennobled if they took over the case law, the "cases", from the fables ... Or if, their masters guided them towards associating the case law with the comic and fabulising spirit of the wise judge

Keywords: Legal ethnology, fable, judicial morals, propensity for justice, public morals, legal and moral decay, Alecu Donici judge, Alecu Donici fabulist.

the verge of the Great Union. His remarkable contribution to the achievement of the ideal millennial), conference held during the Scientific Session "The contribution of the lawyers from Bucovina to the accomplishment of the Great Union", November 28, 2018, "Stefan cel Mare" University from Suceava \& Suceava Bar Association. The text of the conference was delivered for publication in "Analale Muzeului Memorial Simion Florea Marian" from Suceava, under the guidance of Mrs. Aura Brădățan, 2019.

${ }^{3}$ Romulus Vulcănescu, Etnologie juridică (Legal Ethnology), Editura Academiei, Bucharest, 1970, p. 9 : "The following subjects deal with the study of the legal aspects of primitive and popular civilization and culture as constitutive parts of the conception about existence and the world and of the ways of normative organization of life, partially and with unequal theoretical resources: "legal geography", "legal anthropology", "legal sociology" and "legal ethnology". " 


\section{Cuprins}

I. Spiritul sapientogen al literaturii parenetice și al fabulei ...................... 216

II. Alecu Donici, schița unei fișe bio-bibliografice .................................... 225

III. Ordine de drept și ordine morală într-un ad hoc"divan" intelectual al fabulelor

\section{Spiritul sapientogen al literaturii parenetice și al fabulei}

Rutina cea dezamăgitoare în arta de-a percepe dreptul, știința dreptului și spiritul dreptății pe care profesioniştii acestei nobile, regale misiuni sociale le-o inspiră tineilor învățăcei, discipolilor ce vor purta robele grele ale Justiției, s-a instalat odată cu consacrarea pozitivismului juridic în cea mai acablantă manieră peste faldurile catenate ale juridicităţii și ale justițiabilității. Astăzi, aceste "falduri" sunt drepte, țepene, ridicol de prețioase şi de sterile în sensuri jusnaturaliste, cu alte cuvinte, dizarmonice, neorganice, non-naturale. Sunt dominate de spirit uniformist, țeapăn, precum arhitectura noastră anti-gaudiană, insuportabil de inumană, minimalist-cazonă.

Spiritul dominant în drept, în arta perceperii și a studierii lui, a fost, de-a lungul mileniilor, sapientogen, apoftegmatic și poetic. Un spirit melodios și poetic, amintindu-ne de timpurile străvechi, când normele juridice erau exprimate în versuri și erau cântate în acompaniament de citeră, precum la strămoşii noștri agatârşi predacici de pe plaiurile moldo-transilvănene și la geto-dacii din întinsa Țară Românească.

$\mathrm{O}$ anumită sugestie a acestui mod disimulant nomotetic (unul ce codifică în mod real comportamentul nostru de români atașați de ordine, în sens de ordo în baza naturii, de ordine naturală, precum inspiratoarea ordine 
cosmică) se poate regăsi în cărțile de înțelepciune ce au, la noi, o venerabilă tradiție, după protomodelul Ceasornicului domnilor. Parabolele, după model cristic, alegoriile, literatura parenetică românească ${ }^{4}$, adică învățăturile, exortațiile, pildele s-au înmulțit vertiginos și astfel putem înregistra astăzi o pletoră de mari oameni de spirit care au înnobilat acest patrimoniu românesc de sapientologie aplicată, cu rol normativ profilactic, de codificare reală, nu abstractă, a unei etologii umane autohtone, a unei științe a comportamentului comun şi dezirabil, și a unei filosofii behavioriste aferente, care să reflecte morala dominantă, moravurile, năravurile locale și cele împrumutate (multe, degenerescente, nedemne) cu concepte noi cu tot (exempli gratia, noi nu avem, în lexiconul juridic și în jargonul popular nici un concept dacic sau moștenit de la romani pentru mită: toate conceptele sunt împrumutate; bunăoară, de la otomani ne-au rămas, până astăzi, ciubucul, peșcheșul și bacșișul; de la vechii slavi ne-au rămas mita, mito și mâzda; iar din limbile

${ }^{4}$ Valerius M. Ciucă, Lecții de sociologie juridică. Câteva repere $̂$ in sociologia generală a dreptului, Editura Polirom, Iași, 1998, p. 275: " În aceastã categorie de izvoare socio-juridice, la un loc de frunte se aflã "Învãțãturile lui Neagoe Basarab cãtre fiul sãu Theodosie". Alte opere îi urmeazã modelul. Unele, de pe poziții autohtone, precum:- "Sfaturile lui Matei al Mirelor cãtre Alexandru Ilaş";- "Sfaturile Mitropolitului Petru Movilã cãtre fratele sãu, Moise-vodã";- "Ceasornicul Domnilor" - prelucrare a lui N. Costin dupã originalul spaniol al lui Antonio de Guevara);- "Sfaturile creștine și politice", publicate în anul 1715 de Mitropolitul Antim Ivireanul. / Altele au fost redactate de pe poziții fanariote, marcate de anxietãți, psihoze şi fobii, între care remarcăm: - "Sfaturile rãposatului domn Nicolae Mavrocordat cãtre fiul sãu Constantin- vodã" - 1726;- "Teatrul politic" de Ambrosius Marlianus, ș.a.. / Se detașează, între aceste opere parenetice, în primul rând, Invățăturile lui Neagoe Basarab către fiul său Theodosie ("Invățăturile bunului credincios Io Neagoe, voievodul Tării Ungro-Vlahiei carele au învățat pre fiul său Theodosie vodă”), operă originală care "topește” în forme noi influențele bizantine și slave ale anilor 1518-1521. / Din această operă reținem ca obiect al analizei noastre "cuvântul al XX-lea" din partea a doua. Este vorba de un capitol "pentru judecată, care au învățat Ioan Neagoe voievod pre fie-său Theodosie și pre alți domni, pre toți. Cum și în ce chip vor judeca." 
germanice am împrumutat cu voluptate șperțul, de la sperrzug, legăturica de şperacle...).

În această bună tradiție, păstrez mereu pe lângă mine o "camerată" de autori îndrăgiți, apreciați, deosebit de sapienți și-i utilizez ca pe veritabili ghizi prefațatori ai articolelor, conferințelor sau lecțiunilor, capitolelor din cărțile pe care le semnez. Jean Carbonnier, ${ }^{5}$ în opera sa de sociologie juridică, îi consideră inspiratori ai juriștilor. Eu îi consider juriști antemergători, opera lor fiind fundamental, funciarmente juridică (nu folosesc ghilimele sau italice când scriu "operă funciarmente juridică" disimulată în artă pură). Este vorba despre o operă ce face dreptul, morala, spiritul normativ să devină efective. Pentru că, la ce pot servi normele abstracte care nu penetrează conștiințele și sufletele oamenilor, norme fără efectivitate? ${ }^{6}$ Rămân simple fraze, proclamații, vane ideologii, evanescențe ale puterii sterpe. Pe când, sapienții autori la care ne raportăm (aici, în mod țintit, Alecu Donici), de stirpe solomonică, ${ }^{7}$ ei bine, aceștia sunt veritabili învățători ai națiunii noastre, cu rădăcini adânci în spiritualitatea românească şi cu stenic optimism în privinţa viitorului comun şi demn al celor ce se revendică de la ea sau de la

\footnotetext{
${ }^{5}$ Jean Carbonnier, Écrits, Textes rassemblés par Raymond Verdier, Presses Universitaires de France, 2008.

${ }^{6}$ Ibidem, p. 1168 : "La sociologie fait pénétrer dans la science du droit une préoccupation d'effectivité. À quoi bon affirmer la légalité, socialiste ou capitaliste, si ce n'est qu'une déclaration de principe, vide d'application effective?"

${ }^{7}$ Jean Carbonnier, Flexible droit. Pour une sociologie juridique sans rigueur, 7eme édition, L.G.D.J., 1992, p.361 : "La justice de Salomon. (...) Et juriste, néanmoins : le personnage est éminemment juridique. / La prière de Salomon en songe (Isaac Herzog, The Main Institutions of Jewish Law, 1936) c' est la prière du juriste. Ce qu'il demande à Dieu, et qu' il obtient, c' est la sagesse pour dire le droit - pour dire le droit au sein d'une nation."
} 
generozitatea ei. Între ei, strălucesc Ioan Inocențiu Micu-Klein ${ }^{8}$, Theofil Simenschy ${ }^{9}$, Gheorghe Alexandrescu ${ }^{10}$, Virgil Matei ${ }^{11}$, Marțian Cotrău ${ }^{12}$, Eugen și Lucia-Gabriela Munteanu ${ }^{13}$. Toți ar merita să fie trecuți într-o virtuală Carte de înțelepciuni, după modelul francez al lui Fr. Lenoir ${ }^{14}$.

${ }^{8}$ Ioan Inocențiu Micu-Klein, op.cit.: Carte de înțelepciune latină. Illustrium poetarum flores. Florile poeților iluștri, Ediția de Florea Firan și Bogdan Hâncu, Editura Științifică, București, 1992.

9 Theofil Simenschy, Un dicționar al înțelepciunii. Cugetări antice și moderne, (vol. I-IV), Ediție îngrijită de Mihail Grădinaru, Editura Junimea, Iași, 1973. A se vedea și ediția basarabeană: Th. Simenschy, Dicţionarul înţelepciunii. Cugetări antice şi moderne, "ediția a III-a, completată cu 171 cugetări cenzurate", Îngrijită de Gh. Drăgan, Editura "Meridianul 28" a Uniunii Scriitorilor, Chişinău, 1995. A se vedea, mai ales, ediţia din anul 2017 a Editurii Saeculum, București, deoarece, așa cum scria îngrijitorul și prefațatorul ediției, istoricul literar I. Oprișan, în edițiile din perioada comunistă "(...) "Tot ce a ținut de religie şi în primul rând textele biblice, o bună parte din cugetările referitoare la libertate, la egalitate, la dreptul de afirmare al individului în societate, la obligațiile şi calitățile conducătorilor, la democrație şi rolul filosofilor, al intelectualilor, în societate etc. au fost eliminate, dezechilibrându-se întreaga articulație a cărţii: întreaga viziune a autorului despre lume şi viață, şi însuşi mesajul operei." (Rev. "România literară”, Nr. 10/2009, http://www.romlit.ro/dictionarulitelepciunii).

${ }^{10}$ Latine dicta. Citate și expresii latinești, Ediție îngrijită, indici și bibliografie de Ghe. Alexandrescu, Editura Albatros, București, 1992.

11 Virgil Matei, Dicționar de maxime, reflecții, expresii latine comentate (dăruită din biblioteca-i personala de maestrul meu, profesorul Marțian Cotrău, chiar în anul marii sale treceri), Ed. Scripta, București, 1998.

${ }^{12}$ Marțian Cotrău, 1001 gânduri pentru cumpătare, Ediția a II-a, Lector: Mirela Bălan, Editura Apollonia, Iași, 1997, carte la a cărei lansare din data de 2 decembrie 1997, la Casa Cărții din Iași, maestrul a rostit profetica rugăciune cu care a încheiat ultima-i conferință: "Doamne, s-a înserat, ziua de muncă s-a sfârșit; / mă întorc în casa mea, pământul, / nu pentru că sunt ostenit de viață, / ci fiindcă soarele a asfințit" (dr. Iulia Vasiliu, "Despre bătrânețe cu luciditate", Almanahul Presa Bună, 1997, pp. 152-153). A se vedea și Marțian Cotrău, aşa cum a fost, Redactori de carte Acad. Ion Hăulică, Acad. Valeriu D. Cotea, Editura Apollonia, Iași, 1998, p. 40, cu un document olograf al maestrului.

${ }^{13}$ Eugen Munteanu, Lucia-Gabriela Munteanu, Aeterna Latinitas. Mică enciclopedie a gândirii europene în expresie latină, Editura Polirom, Iași, 1996.

${ }^{14}$ Le livre des sagesses. L'aventure spirituelle de l'humanité, Ed. Bayard, Paris, 2005. 
În ceea ce privește fabula, aparent gen literar minor, deplâns de Paul Valéry ${ }^{15}$ ca fiind doar obiect de contemplație istorică, intersecția culturii juridice cu spiritul sapiențial, moral şi literar al poporului se măreşte considerabil; atât de mult, încât devine reper științific prețios în emergenta etnologie juridică înfrățită cu sociologia juridică, cu antropologia juridică și cu folclorul juridic ${ }^{16}$. În modul cel mai serios, chiar dacă, nu-i aşa, cu arme hazlii și caricaturizante, cu spirit şăgalnic şi isteț, fabula decriptează propensiunea unui popor pentru adevăr şi justiție sau, dimpotrivă, fatalism gregar față de viciile ce corup psihologic şi moral națiunea. Rolul ei este didactic. Tinerii juriști ar deveni înnobilați ştiințific şi cultural dacă ar prelua cazuistica, "spețele", din fabule... Sau dacă, maeștrii lor i-ar ghida către asocierea sobrei cazuistici cu spiritul ghiduș și fabulatoriu al judecătorului sapient...

Ce-nseamnă fabula pentru știința dreptului şi, mai ales, pentru etnologia juridică, pentru etnopsihologie și axiologie socială, indispensabile înțelegerii organice, integrative, populare sau comunitare, a operei de legiferare, de guvernare și de înfăptuire a justiției distributive (a distribuirii onorurilor în cadrul justiției și echității sociale) și, mai cu seamă, a justiției

\footnotetext{
${ }^{15}$ Paul Valéry, "Oraison funèbre d'une fable”, în Variétés, apud Sanda Radian, Măștile fabulei. Etape de evoluție în literatura română, Editura Minerva, București, 1983, p. 5: "Puțin câte puțin cei ce le iubeau ori care le gustau, cei care le puteau îțelege dispar. Cei care le cereau, cei care le rupeau, cei care le persiflau au murit și ei... În curând un instrument de plăcere și emoție va deveni accesoriu școlar; ceea ce a constituit adevărul, ceea ce a constituit frumosul se schimbă într-un mijloc de constrângere sau într-un obiect care stârneşte curiozitatea, dar o curiozitate ce se forțează să fie curioasă.”."

16 Romulus Vulcănescu, Etnologie juridică, Editura Academiei, București, 1970, p. 9 : ”Cu studiul aspectelor juridice ale civilizației și culturii primitive și populare ca părți constitutive ale concepției despre existență și lume și ale modurilor de organizare normativă a vieții, se ocupă parțial și cu resurse teoretice inegale: "geografia juridică", "antropologia juridică", "sociologia juridică” și "etnologia juridică"."
} 
comutative (a recunoaşterii drepturilor particularilor în cadrul raporturilor lor juridice contencioase, conflictuale)? Ei bine, din capul locului afirmăm că aportul ei la toate aceste acţiuni de stimulare a comprehensiunii și a devoalării esențelor fenomenelor evocate este imens, consolidând cutuma valoroasă, bine rafinată în timp, sau, cum statuează specialiştii, "dreptul invizibil", criptodreptul $^{17}$. Valoarea contributivă este noetică, nu exotică. Din Antichitatea orientală, trecând prin Grecia și Roma, străbătând Evul Mediu european, fabula a pregătit mereu terenul discursului justițiar și moralizator popular și tot ea a tras concluziile demersurilor sociale eșuate, ca și cum ar fi fost moaşă, într-o maieutică a valorilor juridice, Azrafil, înger al morții, consacrând cu sarcasm, sentențios și crud, relațiile stricate de morbul corupției și al infracțiunilor rușinoase, furtul și abuzul, dar s-a prezentat și ca psihopomp în lumea relațiilor sociale ratate, cangrenate de vicii, de corupție şi de alte rugini ale sufletului colectiv ori ale spiritelor noastre individuale, peste tot unde fabula ne-a pătruns cu morala ei. ${ }^{18}$

Adresându-se sufletului poporului în mod direct, neintermediat, fără "ambasadori" speciali, fabula trebuie întrețesută pe canavaua acelui suflet. Ca atare, fabuliștii sunt buni cunoscători ai acestui suflet colectiv, anticipând

\footnotetext{
17 Romulus Vulcănescu, op.cit., p. 40: ”Criptodreptul deși contrazice și nuanțează norma juridică teoretică oficială, ca şi formele folclorice de drept etnic legate de unele structuri sociale și de valori de grup, este definit, sistematizat și interpretat în spiritul noii concepții etnologice." 18 Antologia fabulei românești de la Dimitrie Țichindeal până la Marin Sorescu, Ediție îngrijită de Adrian Săvoiu, Editura Art, București, 2017, p. 5: "Născută în Orient, unde cele ma vechi motive sunt atribuite autorului indian Bidpay, fabula a apărut pe continentul european încă din secolele VII-VI a.Cr. În Grecia, avându-i precursori pe Arhiloc și Hesiod, specia și-a aflat cea mai mare strălucire în opera lui Esop. Preluată de romani, a fost continuată de Fedru și Avian, care au dezvoltat cu ingeniozitate temele din creația grecului Esop. În perioada Evului Mediu, fabula s-a apropiat de basmul popular prin Romanul lui Renart, o colecție de povești animaliere franceze, culminând în secolul al XVII-lea prin scrierile lui La Fontaine, care a influențat toate creațiile fabulistice din perioada ce a urmat.” (Adrian Săvoiu).
} 
și știința psihologiei sociale ce avea să apară, printre ale umanioare, abia în secolului XX, prin opera omonimă a lui Gustave le Bon. ${ }^{19}$ Or, la noi, Costache Negruzzi, încă din 1835, făcea un mic crochiu, o mică eboşă a sufletului românesc. ${ }^{20}$ Fabula juridic-moralizatoare prelungește în mod natural câmpul noetic, ideatic, "exploatat" în mod natural de folclorul juridic, dar această prelungire iese din sfera anonimatului și se înfățișează ca un gen particular de carmina seducătoare în sfera elitelor literare. De la folclor preia spiritul extrem de ludic, părând a se adresa copiilor ce trebuie călăuziți, cu un oarecare cinism, cum spunea Lamartine, pe făgașul dreptului și moralei. De la literatura cultă preia alegoria, metafora sugestivă şi penetrantă, o adevărată armă mortală pentru cel ce stă prost la capitolul viață cinstită şi morală, dreaptă şi virtuoasă, incoruptibilă și senină. Urmând glorioasei deschideri esopiene a avanscenei criticii sociale de tip moralizator şi juridic, prin La Fontaine cucerește Olimpul poeziei, aşa cum Shakespeare cucerise Parnasul

\footnotetext{
${ }^{19}$ Gustave le Bon, Psychologie des Foules, 1896.

${ }^{20}$ Sanda Radian, op.cit., p. 8: ”(...) în studiul său Scene pitorești din obiceiurile Moldaviei, Cântece populare ale Moldaviei, Costache Negruzzi constata că "istețimea și duhul satiric al poporului românesc se văd în toate cântecele sale" Iar Heliade observa un spirit "caustic, natural la români”. Lovinescu, atunci când vorbește de specificitatea geniului artistic popular, pătrunzând mai adânc în caracterele originalității noastre estetice, subliniază ca trăsături naționale duioșia și sentențiozitatea. (...) Mihai Ralea (...) firea poporului român - bonom, ponderat, mucalit, ascuțit în observație şi, ca tot meridionalul, extrem de lucid (...) ar trebui făcut un capitol special asupra zeflemelei în viața noastră (...) Tudor Vianu, în Asupra caracterelor specifice ale literaturii române, pune în lumină ca dominantă a beletristicii noastre "un clasicism realist" și "înclinarea spre ironie și umor prin care se corectează diformitățile și sunt răzbunate avaniile (umilințele, asupririle, n.m.) realităţii”. Al. Philippide (...) Şi totuși, fără să mai vorbim de Caragiale, unic, inimitabil ca şi Eminescu, există în literatura românească o trainică tradiție de haz și de glumă. Este unul din cele mai sigure elemente tradiționale ale literaturii noastre.” Poporul însuși prin expresia "a face haz de necaz" definește o tendință de a satiriza racilele cotidianului, găsind în glumă o modalitate de defulare. Gluma (libelurile defăimătoare, n.m.) cu o concluzie generalizatoare, cu o "morală", ce vădește o luare de poziție plină de înțelepciune, dar are și un efect justițiar mental, corespunde deci unor caractere etnopsihologice ale națiunii."
} 
tragediei iar Beethoven, Everestul simfoniei, pentru a o parafraza pe Sanda Radian (Măsstile fabulei, cit. supra). Și la Dimitrie Cantemir alegoria este esențială, semnificativă, puternică precum o diatribă ciceoniană din Senat împotriva coruptului vinovat de concupiscență Catulus ${ }^{21}$, dar, de această dată, adresată, prin "romanul" Istoria ieroglifică, Brâncovenilor... Iar noi, românii de mai-ieri și până astăzi, prin Motanul Arpagic al Anei Blandiana, simțeam că am dobândit, cu puțin timp înainte de Revoluția din 1989, un strop de libertate de exprimare într-un ambalaj al "deriziunii" copilărești, unul mai consistent decât orice discurs juridic descriptivist, conformist (cu evanescentul reflex verbal "conf.art., conf.art." sic!) și tiranofil...

Secolul al XIX-lea românesc a înregistrat apogeul fabulisticii în toate provinciile istorice, de la Nistru până la Tisa. După satirele lui Antioh Cantemir ${ }^{22}$, ctitorul Academiei Domnești din Iaşi (1707) şi consolidarea trendului ascendent al criticii sociale moral-juridice prin moldoveanul Gheorghe Asachi ${ }^{23}$, munteanul din Târgoviștea voievodală a Basarabilor, Grigore Alexandrescu ${ }^{24}$ și bănățeanul Dimitrie Țichindeal ${ }^{25}$, tustrei fiind și veritabili pilaștri de bază ai templului conștiinței naționale, după aceste remarcabile fenomene, scena este ocupată de basarabeanul orheean Alecu Donici, care se desăvârșește profesional, prin calitatea de președinte al Judecătoriei Neamț, la Piatra Neamț, iar literar, prin publicațiile și funcțiunile culturale de la Iaşi. Aprecierile ce ne vin de la Mihai Eminescu față de această

\footnotetext{
${ }^{21}$ Marcus Tullius Cicero, In Catilinam orationes quattuor.

${ }^{22}$ Vasile Alecsandri, Satire și alte poetice compuneri de prințul Antioh Cantemir (publicate în periodice).

${ }^{23}$ Fabule versuite, de Gheorghe Asachi, mădular Academiei de Roma şi al mai multor societăți învățate, Ediția a treia, adăogită, Iașii, Institutul Albinei Românești, 1844.

${ }^{24}$ Grigore Mihail Alexandrescu, Meditații, elegii, epistole, satire şi fabule, București,1863.

25 Dimitrie Țichindeal, Fabule și moralnice învățături, Editura Facla, București, 1975.
}

\section{3}


generație de aur a fabulisticii românești, în cunoscuta-i poezie Epigonii, lasă loc de puține comentarii. Iată câteva excerptae:

Văd poeți ce-au scris o limbă, ca un fagure de miere / Cichindeal gură de aur, Mumulean glas cu durere, / Prale firea cea întoarsă, Daniil cel trist și mic, / Văcărescu cântând dulce a iubirii primăvară, / Cantemir croind la planuri din cuțite si pahară, / Beldiman vestind în stihuri pe războiul inimic. / Liră de argint, Sihleanu - Donici cuib dențelepciune, Care, cum rar se întampla, ca să mediteze pune / Urechile ce-s prea lunge ori coarnele de la cerb; / Unde-i boul lui cuminte, unde-i vulpea diplomată? / S-au dus toți, sau dus cu toate pe o cale nenturnată. / S-au dus Pann, fiul Pepelei, cel isteț ca un proverb.

Ca-n orice dezvoltare naturală, organică, acestei epoci avea să-i fie contrapusă o alta, a jurnalismului pasionant, aducând cu sine, în avanscena criticii de moravuri şi de atitudini infracționale, a criticii sociale și juridice în general, caricatura, benzile desenate, până la această contemporană epocă ce limitează forța de cândva a jurnalismului prin forța directă a telematicii, a instantaneității comunicaționale și prin virulența în progresie geometrică a rețelelor de socializare, prin sloganurile extrem de sugestive, de percutante, precum acelea din cadrul manifestațiilor gigantice de stradă ale mișcării \#Rezist din România anilor 2017-2018.

$\mathrm{Cu}$ toate acestea, viața juridică și morală a cetăţii nu poate aneantiza amintirea prețioasă pentru asanarea moravurilor și îngrădirea infracțiunilor a alegoriei fabulistice și a libelurilor defăimătoare de cândva. Acestea au cunoscut mulți detractori (din partea celor vizați sau a acelor care ”s-au simțit cu musca pe căciulă”, pentru a vorbi românește...). 


\section{Alecu Donici, schița unei fișe bio-bibliografice}

Alecu Donici s-a născut în anul 1806. Pe data de 19 ianuarie 1806, a fost botezat în localitatea Piatra-Bezin din ţinutul Orhei ${ }^{26}$ (după străvechea medievală organizare administrativ teritorială în ținuturi și ocoale moldovenești). Era orheean, deci, precum un alt fabulist evidențiat în istoria literaturii române, poetul Ioan Sârbu, născut la Ignăței, în 1830 și decedat la Mașcăuți, tot din ținutul Orhei, în 1868. ${ }^{27}$

Alecu Donici era primul fiu din cei patru ai familiei clucerului Dimitrie Donici (boierului și dregătorului responsabil cu aprovizionarea unei curți domnești în Țara Românească și Moldova feudale) și al Elenei Donici (născută Lambrino). La vârsta de 29 de ani a emigrat la Iași și, după alți șase ani, la Piatra Neamţ, unde, de altfel, a și decedat în aprilie 1865 (George Călinescu face trimitere la un necrolog din oficiosul nemțean Trompeta Carpaților din 15/25 aprilie). Orientarea spre magistratură nu ne este explicată. Știm doar că încă din perioada chișinăueană, când fusese asesor al așa-numitei Judecătorii Regionale a Conștiinței, apoi, din cea ieșeană, când fusese asesor al Curții de Apel, dar mai ales la Piatra Neamţ, unde a devenit agă, prezident al Tribunalului, după ce fusese președinte al Judecătoriei ${ }^{28}$ iar, din 1850 , membru al Curții de Apel, devenind, un an mai târziu, președinte al Divanului de Întărituri, o curte pentru pricini vizând cărțile, întăriturile domnești în

\footnotetext{
${ }^{26}$ Alecu Donici, Fabule şi satire, Editura Litera Internațional, București-Chișinău, 2002, p. 7 .

${ }^{27}$ George Călinescu, Istoria literaturii române de la origini până în prezent, Ediția a II-a, revăzută și adăugită, Ediție și prefață de Alexandru Piru, Editura Minerva, București, 1988, p. 279.

${ }^{28}$ Mihai Răzvan Ungureanu, Marea arhondologie a boierilor Moldovei (1835-1856), Ediția princeps, Editura Universității ”Alexandru Ioan Cuza", Iași, 1997, p. 105: "Donici, Aleco: "prezident Giud(ecăto)riei Neamțul, agă”, 2499/o2.02.1846."
} 
materie de drepturi reale imobiliare, de proprietate, posesie sau scutiri de impozite. Mai știm că un unchi pe linie paternă, Andronache Donici era un jurist celebru al timpului, autorul unui manual-cod privat de legi (pravile) ${ }^{29}$, colaborator la redactarea Codului Calimach și teoretician al dreptului (introducerea la manualul său, "predoslovia", fiind considerată, de către Valentin Al. Georgescu, ca fiind prima operă teoretică de hermeneutică juridică românească, iar autorul ei, supranumit "pravilist”). Să-l fi inspirat acest iluminist moldav, acest savant jurist al timpului, ce-a căutat să modernizeze, pe canavaua dreptului roman și a celui bizantin, dreptul obişnuielnic, obiceiul pământului de la noi? Nu știm cu certitudine. Seamănă cu iluministul său unchi şi sub unghi "ideologic", avant la lettre... Odată ajuns în Iaşi, va adera la curentul de idei naționale şi europene, înnoitoare și liberale promovate de mișcarea europenistă, paşoptistă și unionistă... ${ }^{30}$

Pe lângă activitatea-i intensă de om al justiției, pe lângă dregătoriile onorabil servite, Alecu Donici a jertfit timp și energie pentru cauza unionistă,

\footnotetext{
${ }^{29}$ Andronache Donici, Adunare den pravelile împărăteşti sau alegire cuprinzătoare foarte în scurt, de cele mai trebuincioasă pravele alcătuite cu mare lesnire, spre înţălegerea şi ştïnţa tuturor, Iași, 1806 reeditată în anul 1814, tot la Iași, sub titlul următor: Adunare cuprinzătoare în scurt din cărţile împărăteştilor pravile spre înlesnirea celor ce să îndeletnicesc întru învăţătura lor, cu trimiterea către cărţi, titlu şi capul împărăteştilor pravile (apud Valentin Al. Georgescu, Preemţiunea în istoria dreptului românesc. Dreptul de protimisis în Ţara Românească şi Moldova,1968).

${ }^{30}$ Spre exemplificare, redăm doar prima strofă dintr-o poezie care parcă anticipează poemul eminescian atât de apreciat, Ce-ți doresc eu ție dulce Românie. Alecu Donici, pe această temă a binecuvântărilor de "benefice zâne ursitoare la naștere" scrie poemul Dorința românului din 1862: "Să fie România de-acum în veci unită / Și propăşind în toate să fie ea menită, / La răsărit să-nalțe pavilionu-i sus, / Ca cele de apus." (A. Donici, op.cit., p. 185)
}

\section{6}


după cum deja am menționat, pentru cauze sociale ${ }^{31}$, filotime ${ }^{32}$, dar și pentru ctitorirea şi consolidarea unor faruri strălucitoare de viață intelectuală în țările române, alături de prietenii lui foarte buni, de-o viață, precum C. Negruzzi $^{33}$ și D. Alexandrescu ${ }^{34}$, sau față de tovarăşsi săi militanți, dominați de aspirații unioniste. ${ }^{35}$

Activitatea literară, munca de creație (ce s-au dovedit a fi pagini de aur ale rechizitoriilor necesare pentru îndreptarea unor innacceptabile stări de lucruri din Moldova) $)^{36}$ au completat în mod fericit acest tablou al dedicației sociale şi familiale (vorbim despre un tată de familie cu zece copii...). Peste 80 de fabule, câteva dintre ele originale, sau, mai bine, cu tematică şi valoare originală, la care se adaugă redeșteptatele satire cantemirești, poeziile, odele,

31 În 1842, din motive de "pricini de judecată", călătorește la București iar în 1852 este ales membru al Divanului Obştesc (A. Donici, op.cit., pp. 7-11).

32 Bunăoară, în anii 1829-1830, a participat la lucrările, acțiunile comisiei din Ciuciuleni, Basarabia, pentru combaterea ciumei pandemice (A. Donici, op.cit., p. 7).

${ }^{33}$ Cornelia Mosora, ”Alexandru Donici”, în Al. Donici, Fabule, Ediție îngrijită , note și prefață de Cornelia Mosora, Editura Tineretului, 1960, p. 5: "Între anii 1821-1823, Alexandru Donici se află cu familia la Chișinău unde se refugiaseră mulți boieri moldoveni (N.B.!, tulburările începutului mișcării Eteriei..., n.m.). Printre refugiații din Moldova se afla în acest oraș și familia poetului Costache Conachi, a lui Costache Negruzzi, Beldiman și alții. / $\mathrm{Cu}$ acest prilej, Al. Donici se împrietenește cu Costache Negruzzi. Cam de aceeași vârstă - Costache Negruzzi era cu doi ani mai tânăr decât Donici - cei doi prieteni se simt uniți de aceleași idei înnoitoare de care sunt animați (...)”.

${ }^{34}$ Ibidem, p. 7: ”După înăbușirea mișcării revoluționare din Moldova, Donici se apropie de grupul militanților pentru unirea Țărilor Române: M. Kogălniceanu, V. Alecsandri, Alecu Russo, oglindind și mai pregnant în fabulele sale realitățile sociale ale vremii, năzuințele unioniste ale poporului."

35 În anul 1855, împreună cu Gheorghe Asachi și Costache Negruzzi, formează Comitetul Teatral, hărăzit a stabili repertoriul Teatrului Național din Iași (A. Donici, op.cit., p. 11).

${ }^{36}$ Cornelia Mosora, loc. cit., p. 11, citândul pe Emil Boldan, "Prefața" la Al. Donici, Fabule, E.S.P.L.A., București, 1958, p. 18: "În condițiile acestea de crunt despotism feudal, fabula cu vestmântul ei alegoric era cel mai nimerit mijloc pentru scriitori ca să-și exprime revolta împotriva asupririi poporului, să demaște oprimarea, fărădelegile stăpânirii.”

\section{7}


traducerile, toate acestea dau conținut major unei opere ce-a fost extrem de bine receptată în țările românești (Eminescu, Kogălniceanu, Negruzzi, Haşdeu, Alecsandri, Iorga, Călinescu ${ }^{37}$ și alții, până la academicianul Mihai Cimpoi al zilelor noastre prezentându-le laudativ, la unison), ceea ce ilustrează propensiunea românilor pentru moravuri bune și pentru justiție impecabilă. ${ }^{38}$

\section{Ordine de drept și ordine morală într-un ad hoc "divan" intelectual al fabulelor}

Pornim de la premisa că fabula este un alt mod de ”a spune" dreptul și morala (Dire le droit, faire justice) ${ }^{39}$, resimțite a fi naturale, de esență jusnaturalistă, în popor. Spre deosebire de infra-dreptul sau dreptulfolcloric ce nu are linii tangente cu ale celui statal, dacă am trata problema în termenii lui Jean Carbonnier ${ }^{40}$, fabula tratează dreptul și morala etatice și "savante". Doar "armele" ei sunt "folclorice". Coținutul este "savant".

\footnotetext{
${ }^{37}$ George Călinescu, op.cit., p. 279: ”Apoi vin fabuliștii, căci acest gen a crescut ca troscotul și nu e poet care să nu fi scris fabule. (...) Al. Donici (...) e cel mai reputat."

${ }^{38}$ Mircea Scarlat, Istoria poeziei românești, Vol. I, Editura Minerva, București, 1982, p. 342: "Basarabeanul Alecu Donici se impune în epocă, astfel încât ediția de Fabule (Iași, 1840) va fi sporită și reeditată în 1842. Puțini sunt, de altfel, scriitorii vremii care nu scriu fabule. Specia e ilustrată de Asachi, Gr. Alexandrescu, Anton Pann, Heliade, Stamati, C. Bălăcescu, Bolintineanu, Mureșanu, G. Sion, D. Ralet și mulți alții. Scriitori de vârste și înzestrări diferite, crezând în valoarea instrumentală a poeziei (iată, mă gândesc aici și la destinul alegoric al Motanului Arpagic al Anei Blandiana..., n.m.), apelează la fabulă în scopuri de cele mai multe ori extraliterare."

${ }^{39}$ François Ost, Dire le droit, faire justice, IIème edition, Ed. Bruylant, Bruxelles, 2007.

${ }^{40}$ Jean Carbonnier, op.cit., (Flexible droit), p. 24.
} 
În cele ce urmează, vom extrage câteva dintre marile teme sociojuridice care formează nucleul justițiarismului social al operei lui Alecu Donici. Temele le anunțăm în litere îngroșate, iar textele selectate după criteriul prezenței elementelor juridico-morale ce formează substanța multor cercetări de etnologie juridică (normele morale și penale ale unui popor fiind imaginea adevăratei sale Constituții, una a esențelor, a fibrei interioare, a spiritului profund şi durabil, nu doar a instituțiilor, a formelor, a modelor pasagere...), ei bine, pe aceste selectate texte le vom scrie cu caractere italice, respectând, însă cu scrupulozitate grafia şi stilul, lexiconul şi gramatica originale și, în acest fel, omagiind cum se cuvine personalitatea copleşitoare a acestui judecător şi fabulist basarabean, desăvârşit român unionist şi înflăcărat adept al moralei paşoptiste noi, naţionale și europene.

A) Corupția şi semnele vizibile, exterioare, ale omului corupt (om învins, cumpărat, slugă corupătorului, după Demostene) $)^{41}$, între care, "strălucește" averea nejustificată, vilele, palatele, imensele acareturi, terenuri întinse și fără număr, toate dobândite din funcțiile publice, din dregătoriile puse în slujba unor mecanisme lucrative într-un cerc restrâns de profitori familiali sau de "amici" de speță oligarhică. Aici, infracțiunea de luare și dare de mită reprezintă cununa de preț a "piraților" de pe covertă... Tabloul lui Vasile Alecsandri, nu atât din seriile lui de Chirițe (anticipând fabulosul

\footnotetext{
${ }^{41}$ Demostene, Pentru coroană (pledoarie cu parti-pris, discurs judiciar într-un proces în care a pledat pro domo) : ”După cum cel care corupe îl învinge pe cel care primește, tot aşa, cel care nu primește îl învinge pe cel care vrea să-l corupă”, apud Theofil Simenschy, op.cit., p. 138. Pentru discursul integral, a se vedea Demostene. Eschine. Licurg. Pagini alese din oratori greci, Antologie, note biografice şi traducere de Andrei Marin, Note explicative de MariaMarinescu-Himu, Vol. II, Editura pentru Literatură, București, 1969, pp. 194-235.
} 
roman Craii de Curtea Veche al lui Mateiu Caragiale), cât din magnificul său roman Dridri (închinat nefericitei sale iubiri) este cât se poate de sugestiv. ${ }^{42}$

Vulpea și bursucul: Da dincotro şi unde / Alergi tu aşa iute? / Bursucul întâlnind pe vulpe-au întrebat. / - Oh, dragă cumătre, am dat peste păcat, / Sunt, iată. Surghiunită! / Tu știi că eu am fost în slujbă rânduită / La o găinărie. / Cu trebile ce-aveam, odihna-mi am lăsat, / Și sănătatea mi-am stricat; / Dar tot eu am căzut în groaznică urgie, / Pe niște pâri nedovedite, / Precum că luam mite. / Tu singur martor ești, în adevăr să spui: / De m-ai văzut cumva, măcar cu vreun pui? / $\mathrm{Nu}$, dragă cumătră; dar când ne întâlneam / Eu cam ades vedeam: / Că tu pe botișor / Aveai și pufușor. / Se-ntâmplă și la noi de vezi / Cum altul, având loc, așa se tânguiește, / Încât îți vine mai să-l crezi / Că abia din leafă se hrănește. / Dar astăzi butcă, mâine cai, / De unde oare-i vin? Și când ar vrea să stai / Să-i faci curată socoteală /

42 Vasile Alecsandri, Dridi, E.S.P.L.A., București, 1960, pp. 39-42, apud Cornelia Mosora, op.cit., p. 10: "Aşadar, în vârful scării sociale un domn cu topuzul în mână şi cu legea sub picioare; pe treptele acelei scări o boierime ghiftuită de privilegiuri, bucurându-se de toate drepturile, până şi de ilegalități, şi scutită de orice îndatorire către țară; alături cu acea boierime un cler1 ai cărui şefi, veniți de la Fanar şi din bizuniile muntelui Athos, se desfătau într-o viață de lux trândavă şi scandaloasă; iar jos, în pulbere, o gloată cu cerbicea plecată sub toate sarcinile! Sus, puterea egoistă, jos, şerbirea şi mizeria fără protecție, şi totul mişcându-se întro atmosferă neguroasă de ignoranță, de superstiții, de pretenții, de lăcomie şi de frică. ... / ... Mituirea, departe a fi considerată ca un delict sau ca un păcat, cum se zicea atunci, intrase adânc în obiceiuri, (grație corumperii de moravuri lățite în țară prin fatala domnire a fanarioților, şi producea, pe lângă lefi, venituri sigure şi permise funcţionarilor. Ea forma rodurile cele mai mănoase din ramurile administrației şi ale justiției, astfel că un slujbaş al statului care în trei ani de serviciu nu-şi făcea avere cădea sub disprețul guvernului. Însuși clerul se îndulcea de păcatul mituirii, prin fabricarea plătită de preoți şi protopopi şi mai cu seamă prin înlesnirea despărțeniilor pronunțate de Dicasterie... /) ... În fine se pierdea în umbră, în părăsire, în ignoranță poporul !... Poporul şerbit boierescului, poporul pe capul căruia toți erau stăpâni, toți : vătavi, arendaşi, proprietari, slujitori, cenuşeri, țârcovnici, revizori, sameşi, ispravnici, judecători, directori, miniştri, domn, sultan şi împărat !... Poporul supus la beilicuri, supus la biruri, supus la dare de flăcăi la oaste, supus la bătaie cu biciul, supus la supliciul fumului prin temnițe, expus la toate capriciile crude ale soartei, la toate mizeriile morale şi fizice, plecat la toți, fie indigeni sau străini, sărăcit, înjosit, cuprins de groază din copilărie până la moarte şi neapărat de lege nici măcar în contra crimelor !" (De fapt, textele de mai sus fac parte dintr-o lucrare prefațatoare a romanului, Constantin Negruzzi. Introducere la scrierile lui, alături de altele de același gen, oarecum memorialistic, dedicate altor personalităţi remarcabile și prieteni ai României, precu, exempli gratia, poetul Alphonse de Lamartine).

\section{0}


Pentru venit și cheltuială, / N-ai zice ca bursucul că are pufușor / Pe botişor? ${ }^{43}$

B) Despre impostura profesională şi infracțiunile de malpraxis avant la lettre, pe care şi spirite luminate, marcate de mizantropie şi justițiarism, precum modelul lor european, dublinezul Jonathan Swift, autorul romanului satiric Călătoriile lui Gulliver ${ }^{44}$, au încercat să le traducă în termeni juridici și să le introducă în legiuirile moderne.

La mormântul unui doctor: Sub astă piatră zace un doctor învățat; / Cu moartea lui de moarte pe mulți el a scăpat. ${ }^{45}$

C) Când recidiva devine, iremediabil modus vivendi et operandi (altfel spus, Lupul îşi schimbă părul, dar năravul ba...), ceea ce a fost temă de meditație la Seneca şi la cei încrezători în sentențiile din Epistolele lui (Desinit esse remedio locus, ubi quae fuerant vitia, mores sunt $)^{46}$.

Lupul și cucul: - Rămâi sănătos, vecine! / Au zis lupul către cuc. / Aceste țări de rău pline / Le părăsesc și mă duc. / Nu mai pot trăi aice, / De om, câine, prigonit. / În Arcadia, ferice! / Este codru de trăit. / Unde aurita vreme / Împărățește deplin, / Unde lupul nu se teme / De năpăstile ce-i vin. / Acolo nu sunt războaie, / Toți în pace viețuiesc: / Omul este blând ca oaie, / Iar câinii nici hămăiesc. / - Cale bună, măi vecine! / Dar te rog, să-mi spui curat: / Năravul nu-ți iei cu tine? / Și colții ai lepădat? / - Să-i lepăd? Da' cum se poate? / - Apoi ține minte, frate, / Că la viitoarea iarnă / Ai să rămâi fără blană. / Și aşa s-au întâmplat, / Precum cucul i-au cântat. / Între

\footnotetext{
${ }^{43}$ Al. Donici, op.cit., p. 21.

${ }^{44}$ Jonathan Swift, Călătoriile lui Gulliver, 3, 2: "O infirmitate a naturii umane, foarte comună, ne înclină să fim mai curioși și mai încrezuți în chestiuni care ne privesc cel mai puțin și pentru care suntem cel mai puțin capabili, fie prin studiu, fie din natură”, apud Th. Simenschy, op.cit., p. 328.

${ }^{45}$ Al. Donici, op.cit., p. 184.

${ }^{46}$ Seneca, Epistulae morales ad Lucilium, 28, 7: ”Nu mai este loc pentru remediu; acolo unde a fost viciu, a devenit obicei", apud Th. Simenschy, op.cit., p. 833.
} 
oameni iar sunt unii / Cu colți de lup înzestrați: / Ori în care partea lumii, / Ei vor fi tot ne-mpăcați. ${ }^{47}$

D) Tema uzurpării și a imposturii: Quod nullum est nullum producit effectum (cu variantele : Quod ab initio vitiosum est, non potest tractu temporis convalescere; quod ab initio nullum est nullo lapsu temporis convaiescere potest) ceea ce relevă şi adevărata semnificație a loviturilor de stat (usurpatio Regibus...); și aceasta, după Regula catoniană, un principiu perpetuu înscris, de la dacul împărat roman Licinius ${ }^{48}$, în Digestele justiniene - De diversis regulis juris antiqui - Quae ab initio inutilis fuit institutio, ex postfacto convalescere non potest $)^{49} ;($...) când să dobândească un "chip", după asemănarea actanților lor, acești protagoniști ai narațiunii publice, acești "regi" ai pădurii, devoți ai "cultului Artemisei", care în numele "luptei

\begin{abstract}
${ }^{47}$ Alecu Donici, op.cit., p. 18.
48 Gaius Valerius Licinianus Licinius Augustus, împărat roman născut din părinți daci în Moesia Inferior, coautor, alături de împăratul Constantin cel Mare, al faimosului Edict de la Milan, edictul toleranței față de creștini, din februarie 313 p.Cr.A se vedea, în acest sens, Justinian, Digestorum sev Pandectarum, Liber L, 17. 210 : Quae ab initio inutilis fuit institutio, ex postfacto convalescere non potest.

49 Valerius M. Ciucă, ”Regele ca sinecdocă a istoriei”, în Daniel Șandru si Alexandru Muraru, editori, Reîntoarcerea. După 20 de ani. Două decenii de la revenirea în țară a Familiei Regale a României, carte în curs de apariție, în cinstea Centenarului unității statale românești, 2018 : "Regula a cunoscut mai multe versiuni, toate susținând principiul după care un act nul de început nu poate fi validat de trecerea timpului. Factualitatea, în sine, nu înseamnă juridicitate. Chiar și în materie de "uzucapiune", de possessio ad usucapionem, sunt necesare, pe lângă corpus, factualitatea pură, animus sibi habendi, o voință recunoscută, de aprehendare, nu de "executare", și, peste toate, de un justum titulus, de un titlu legal, diferențiat de actele furtive... Printre cele mai importante expresii cu această semnificație, pe lângă aceea prezentată mai sus, le reținem, pentru scopul circumstanțiat al acestei lucrări, pe următoarele :
\end{abstract}

Quod ab initio non valet, in tractu temporis non convalescere ;

Quod ab initio vitiosum est, non potest tractu temporis convalescere ;

Quod nullum est, nullum producit effectum ;

Quod nullum est nullo lapsu temporis convalescere potest ;

Non firmatur tractu temporis, quod de jure ab initio non subsistit etc." 
drepte finale" uzurpă regele și emasculează sacerdotul, dispar finalmente, "arși între coloane", precum cei ce-au eșuat lamentabil în labirintul tenebroaselor istorii ale şantajului ${ }^{50}$, ale corupției, sau, încoronați cu lauri, se topesc în cronologii "votive", dar sterili în progenituri care să le perpetueze maleficul model; aceștia din urmă devin mai trecători ca libelula pe luciul unei ape curgătoare...” ${ }^{\prime 51}$

Parnas: Pe când la greci au părăsit / Ciopliții dumnezei, / Iar locurile lor, pe drept le-au împărțit / Norodul între ei: / Atunci și muntele Parnas / La unul muritor moșie a rămas. / Stăpânul nou pe el îndat-au așezat / Câțiva măgari la păşunat. / Măgarii au aflat, / De unde, până unde! / Că muzele odat' / Au locuit pe munte / Și zic: "Se vede, dar, / Că noi aici suntem mânați nu în zadar. / Pesemne muzele de oameni s-au urât / Şi ei au hotărât: / Ca noi în locul lor cântări să iscodim. / Aideți! voinicilor! cu toții să răcnim. / Nu pierdeți cumpătul, strigați cu îndrăzneală, / Iar cine n-are glas / Cum trebui la măgari, afar' de pe Parnas! / Și credeți că, păzind această rânduială, / Noi slavă vom lua, mai mult răsunătoare, / Decât acele nouă vestite sorioare". / Acest sfat măgăresc, / Măgarii cu un glas îl îmbunătățesc. / Și-odată toți pornesc / Așa strigare mare, / Încât stăpânul lor, pierzând toată răbdarea, / Au poruncit

\footnotetext{
50 ”Groza se prezintă la rege și depune jurământul. Regele vede în el un ins prefăcut, care se crede foarte spiritual copleșindu-și interlocutorii cu glume vulgare. Pe scurt spus, un individ "unsuros". Peste câteva ore sosesc Vîșinski și Malinovski, care salută decizia regelui și numirea noului premier. Regina Elena notează într-un carnețel : "Am aflat că, dacă Mihai nu accepta guvernul astăzi, Malinovski l-ar fi arestat în această noapte şi l-ar fi dus la Moscova. La acest gând, îmi îngheață sângele în vine. Și astfel se încheie o săptămână de tensiune și disperare.” E 6 martie 1945." - text extras din Tatiana Niculescu Bran, Mihai I. Ultimul rege al românilor, Ed. Humanitas, București, 2016, p.220.

${ }^{51}$ Valerius M. Ciucă, ”Regele ca sinecdocă a istoriei”, loc. cit.
} 
cu ură / Să-nchidă pe măgari, de pe Parnas, la şură. / Eu vreau saduc aminte: / Că locul nu dă minte..$^{52}$

E) Decât o judecată bună, mai bine o înțelegere proastă. Este o temă pe care înțelepții o numesc "a perdantei căi adversariale", cu cheltuieli de judecată, riscuri, timp pierdut și stres emoțional și intelectual versus calea cea bună, conciliară, compromisorie, a medierii. Dintotdeauna, adversitatea a pierdut teren în fața clemenței (clementia) ${ }^{53}$ sub aspectul valorilor umane dobândite. Şi Anton Pann dedică două Povești ale vorbei acestei fabuloase teme antice. ${ }^{54}$

Momița și două mâțe: În a momițelor țară / (Ce mai nu are hotară) / Odată judecătoare Era o momiță, care / Chibzuia cu scumpătate / Cumpăna cea de dreptate. / Și iată că la momiță / Se arată două mâțe, / Zgâriate, încruntate, / În prigonire de moarte, / Părăsind al lor lăcaş, / Pentr-un bulgăre de caș. / Una strigă: "Socotește! / Caşul eu l-am fost ochit." / Alta țipă: "Hotărăște! / Caşul eu l-am dobândit." / - Stați! le zise lor momița. / În cumpăna de dreptate / Se va lămuri ființa / Pricinii de caş urmate. / Apoi caşul drept în două / Rumpându-l ea prea frumos, / Au pus întru amândouă / Cumpene câte un boț. / Dar când cumpăna ridică, / Vede c-o parte-i mai mică; / Mușcă, cearcă, chibzuiește / Şi bine nu nimerește. / Acum partea cea muşcată / Nu trăgea ca ceialaltă; / Mușcând iar din acea grea, / Tocmai drept nu nimerea. / Și așa

\footnotetext{
${ }^{52}$ Alecu Donici, op.cit., pp. 25-26.

${ }^{53}$ Yuval Noah Harari, Sapiens. Scurtă istorie a omenirii, Traducere de Adrian Șerban, Editura Polirom, Iași, 2017, p. 138 :(clementia) "Aceasta e materia din care sunt făcuți creatorii imperiilor. Incompetent din punct de vedere militar, Augustus a reuşit să instituie un regim imperial stabil, realizând ceva ce nu au reușit nici Julius Caesar, nici Alexandru cel Mare, care erau generali mult mai competenți. Atât contemporanii săi care l-au admirat, cât și istoricii moderni atribuieadesea această înfăptuire virtuții lui Augustus de clementia - blândețe și clemență.”

${ }^{54}$ Anton Pann, Povestea vorbii, ”Despre pricini de judecăți”, după Culegere de Proverburi sau Povestea Vorbii - De prin lume adunate și iarăşi la lume date (3 vol., București, 1852-1853, în Tipografia lui Anton Pann), Text stabilit și glosar de I. Fischer, Precuvântare de Ion Roman, Ilustrații de Eugen Taru, Editura de Stat pentru Literatură şi Artă, 1958, pp. 286-287.
} 
pân-în sfârșit / Tot în cumpene au tras; / Iar mâțele s-au trezit / Că din caș n-au mai rămas. ${ }^{55}$

F) Pars leonina în partajul necinstit din "grupurile necinstei". Este un domeniu unde epilogul precede fabulei, întrucât, în grupările infracționale, judecata dreaptă este inversată, pilastrul central al "moralei esoterice" a lor, al regulilor intrinsece, precum în oligarhicul Leviathan hobbesian ${ }^{56}$, fiind constituit din principiul oligarhic al "puterii pure", nu al rațiunii sau al "fraternității", al echității (aequitas) quasi-sociale...

Leul la vânat: Leul, lupul, vulpea şi câinele odat', / Ca niște buni vecini, s-au fost alcătuit, / Cu toții întrunit, / Să umble la vânat: / Și ce vor căpăta să-mpartă măsurat. / Se-ntâmplă dar, că vulpea-ntâi / Un cerb frumos au prins, / Și adunând pe toți ai săi, / Spre jertfă l-au întins. / - Acuma e treaba mea, băieți, / Le zise leul lor. / Voi trebui numai să vedeți / Cum eu împart ușor. / Și despicând îndat' pe cerb în patru părți, / Au zis: "Aceste sunt frățeștile bucăți. / Şi iată: cea întâi e partea mea de frate; / A doua, pe drept ca unui leu se cade; / Ș-acea a treia tot mie se cuvine, / Precum voi știți prea bine. / Iar de a patra, oricare s-ar atinge, / Pe loc îl voi învinge..$^{57}$

G) Vizibilitatea funcției publice este incompatibilă cu transgresiunea legii şi a comandamentelor morale ai căror gardieni naturali sunt presa liberă, independentă și Justiția independentă, egida tuturor libertăților fundamentale, aici interesând libertatea de expresie, a cuvântului, sufletul tuturor libertăților, după Demostene ${ }^{58}$. ”Funcția publică" este dotată cu un

\footnotetext{
${ }^{55}$ Al. Donici, op.cit., pp. 27-28.

56 Thomas Hobbes, Leviathan (Leviathan, sive De materia, forma, \& potestate civitatis ecclesiasticae et civilis), 1668.

${ }^{57}$ Al. Donici, op.cit., p. 40.

${ }^{58}$ Demostene, Filipice, 2, 25, apud Stobaeus, Florilegium, 13, 17, apud Th. Simenschy, op.cit., p. 419: "Nu poate fi o nenorocire mai mare pentru oamenii liberi decât pierderea libertății cuvântului”. Vezi și Demostene. Eschine. Licurg. Pagini alese din oratori greci, op.cit., vol. II, pp. 77-92.
} 
"clopoțel" special şi cu un legitim sporit control social având în vedere anvergura ei dar și consecințele dezastruoase ale încălcării normelor juridicomorale. A continua, eventual, ca, în timpul exercitării funcției publice, un astfel de funcționar să dea măsura tarelor sale morale şi exacerbării intereselor sale personale, pricopsirii sale şi a familiei sale, în dispreţul rezervei, decenței, quasi-"sfințeniei”, exemplarității, impecabilei conduite publice și private, ei bine, în mod legitim trebuie să sune "clopoțelul", adică să fie devoalate toate aceste malefice conduite de către o presă liberă, nestingherită în opera-i de asanare morală, percutantă. La fel, prin prisma libertăţii de opinie şi a cuvântului, "clopoțelul de argint" cu care toți suntem în mod natural dotați, comentariile, aprecierile, luările de poziție folosesc operei paideice generale de educare a vlăstarelor societăților noastre în spiritul etic, moral, juridic dezirabil.

Magariul: La un țăran era o vită de măgar, / Cu care el la toți se lăuda; / Căci în părerea lui prea bine se purta. / Şi pentru cămprejur era tot codri mari, / Apoi ca nu cumva, păscând, să rătăcească / Măgarul lăudat, / Şi totodată vrând ca să-l împodobească, / Un zurgălău la gât țăranul i-au legat; / Măgarul sau făcut măreț și îngâmfat. / (De decorații el pesemne auzise, / Că prea se fudulise.) / Dar rangul nou au fost lui spre osândă mare. / (Urmează şi la noi această întâmplare.) / Eu însă mai întâi dator sunt să vă spun, / Că în purtări era măgarul nu prea bun; / Iar pân' la zurgăău el bine petrecea. / Prin țarini, prin grădini, prin curături umbla, / Păş̧tea, se-ndestula; / Ş-apoi cam pe furiş acasă sentorcea. / Acum însă mai rău măgarul petrecea. / Pentru că rangul nou, / Sunând prin zurgălău, / Chema când pe vecin cu vro despicătură / Să deie pe măgar afar' din curătură, / Când pe stăpânul său cu jărdia în mână, / Să-l scoată din grădină;/ Apoi și pe jitar,/ Să-i rupă coastele cu parul din ogoară, / Încât bietul măgar, / Stâlcit și osândit, rămase mai să moară. / Și oamenii acei la rang înaintați / Pățesc asemene, când sunt interesați; / Pentru că 
rangul nou, / Lor este zurgălău, / Ce sună de departe / Vădindu-le a lor fapte. ${ }^{59}$

H) Însuşirea nelegitimă, injustă, ilegală a muncii altuia, cu simularea efortului și cu nedemnul comportament aferat și arogant al acestor furi, această nedemnă conduită, una care, în viața intelectuală a cetății dobândește alura plagiatului, a anticului plagium ${ }^{60}$, ca o "răpire" sau fraudă cu sclavi ${ }^{61}$ pentru extorcare ulterioară, în profit personal, a reprezentat dintotdeauna ținta unor diatribe publice sau a astuțiilor moraliștilor și ale juriștilor veritabili, cei preocupați de starea moralei publice şi de posibilitatea de înrâurire a vieții juridice prin comandamentele ei universale, perene, kantiene.

Musca: De la arat un plug / Venea încet spre casă / Și, la un bou pe jug, / O muscă se-așezase. / Iar ei, spre-ntâmpinare, / O altă muscăn zbor / Îi face întrebare: / - De unde, dragă sor'? / - Și mai întrebi de unde! / Ei musca îi răspunde / C-un aer supărat. / Au nu pricepi ce facem? / Nu vezi că noi ne-ntoarcem / Din câmp, de la arat! / Spre laudă deșartă / Mulți zic: noi am lucrat, / Când ei lucrează-n faptă, / Ca musca la arat. ${ }^{62}$

I) De ce este nevoie de cazier alb, impecabil în funcțiile publice? De ce este necesară chestionarea victimelor atunci când sunt luate hotărâri cu privire la reprezentarea lor în ierarhiile sociale? De ce este inadmisibil, moralmente și din perspectivă juridică, numirea unui ”lup nazâr, stăpân,

\footnotetext{
59 Antologia fabulei românești de la Dimitrie Țichindeal până la Marin Sorescu, Ediție îngrijită de Adrian Săvoiu, Editura Art, București, 2017, pp. 74-75.

${ }^{60}$ Lex Fabia de plagiarïs (63 a.Cr.). Vezi și Marcus Tullius Cicero, Pro Rabirio Postumo, 8,7. ${ }^{61}$ Justinian, Digestorum sev Pandectarum, Liber XLVIII, 15.

${ }^{62}$ Al. Donici, Fabule, Ediție îngrijită de Valeriu Ciobanu, Cu o prefaţă de Emil Boldan, ”Din periodice: Foaie științifică şi literară, I (1844), p. 80”, Editura de Stat pentru Literatură și Artă, 1956, p. 151.
} 
administrator la oi”? Aceasta este o măsură antică de precauție socială, una care introduce parțial principiul meritocrației în tot ce înseamnă administrație publică și, prin extrapolare, în toate funcțiunile, profesiile și ipostazele publice (în multe situații, chiar private), pentru a fi înlăturate premisele favorabile unor pierderi de ordin material, moral, sau, doar simbolic (dacă nu cumva această din urmă pierdere socială este și cea mai grea...). Chiar dacă nu exista un cazier modern, în sens de Criminocorpus, exempli gratia, în Roma republicană îi revenea cenzorului (cu funcțiunea unui serviciu de informații avant la lettre) să informeze Adunarea Poporului și Senatul, mai ales, la alegeri, cu privire la profilul moral al candidaților, demascându-le tarele comportamentale și trecutul delictual și imoral. Până astăzi ne-a rămas legenda marelui cenzor Marcus Porcius Cato (supranumit cel Bătrân, sau Cenzorul, sau Major). Indro Montanelli ${ }^{63}$ folosește o anecdotă cât se poate de edificatoare: la pretenţia unui candidat că rănile de pe trup iau produse de inamici, în război, cenzorul îi amintește de "luptele" cu matroana din bucătărie... Interdicția normativă de acest gen (mai ales pe cale cutumiară, consuetudinară) a exercitat, de-a lungul mileniilor, în toate civilizațiile consacrate, și un puternic rol profilactic, antitransgresiune, dar, mai ales, unul paideumatic, didactic pentru vlăstarele naţiunilor, regatelor, statelor etc. Tema este cu adevărat universală, ținând de morala publică sănătoasă.

Lupul nazâr: Oricât de bune rânduiele, / Cum vor intra pe mîini de oameni necinstiți/ Și numai de al lor folos povățuiți, / Se fac îndată rele. / Spre pildă trebuie să știți / Că lupul s-au cerut la leu nazâr pe oi. / Se vede că la el, precum și pe la noi, / Tot trebui mijlociri, / Căci el întâi au pus pe vulpe meșteriță, / Rege către leiță.

${ }^{63}$ Indro Montanelli, Roma. O istorie inedită, Traducere de George Miciacio, Editura Artemis, București, 1995 . 
/ Dar, pentru că de lupi sunt rele auziri, / Prealuminatul leu ferind nemulțumiri, / A poruncit la sfat / Să facă tuturor chemare / De o obștească adunare, / La care mic și mare să fie întrebat: / Ce știu de lup și ce purtări el are. / Așadar, fiarele pe rând s-au adunat / Și întru o unire glas bun de lup au dat. / Pe urmă au ieșit porunca cea leiască: / Pe lup, nazâr deplin, la stâne să-l pornească. / Dar oile ceau arătat? / La adunare ele au fost neapărat? / Aceasta-i de mirare, / Că sfatul au uitat să facă lor chemare, / Când ele mai ales erau trebuitoare. ${ }^{64}$

J) Cam în aceeași notă a imposturii de destin, precum în exemplul precedent, Alecu Donici introduce tema pe care noi, modernii, o numim infracțiunea de abuz în serviciu în formă agravată, o infracțiune în mod natural, precum furtul, fără ”prag” inferior valoric, deoarece, aşa cum a fost și denumită și fiind circumstanțială, vizează serviciul și nu patrimoniul sau, așa cum îmi place să spun, este poliedrică și neregulată, deoarece sunt vizate toate serviciile, toate ocupațiile omenești ce acoperă spațiul public și privat al vieții noastre sociale. Sursa îndepărtată a tuturor formelor incriminate de abuz se află în străvechiul abuz de încredere. Sunt, toate, "fructe" perene ale aceluiaşi "arbore" ale cărui ramuri au ADN-uri diferite, arborele credinței, al bunei-credințe (bona fides) ${ }^{65}$. Denaturarea destinației acestor "fructe" se poate face prin furt sau prin abuz, sau prin ambele concomitent, aceste fapte ignobile prin definiție neexcluzându-se una pe alta. Această rădăcină comună a conduitelor abuzive asigură confluența unei conduite dolosive cu una de escamotare, de acoperire, o componentă magică. Nici în raporturile private această atitudine n-a fost acceptată; cu atât mai puțin în cele publice.

\footnotetext{
${ }^{64}$ Alecu Donici, Fabule și satire, Ed. Litera Internațional, București-Chișinău, 2004, p. 56.

${ }^{65}$ Valerius M. Ciucă, ”Bona fides într-o nouă hermeneutică”, în Vagant prin ideea europeană. Fulgurații juridico-filosofice, Editura Fundației Academice AXIS, Iași, 2012, pp. 159-175.
} 
Ursul la priseci: La o alegere, făcută după legi / Ce dobitoacele povățuiesc din veci, / Pe urs l-au fost ales nazâr peste priseci, / Deși sar fi putut un alt, oricare fie, / Să prindă o așa cam grea dregătorie. / Căci ursul dacă dă de miere, / Apoi se-ncurcă-n socotele. / Dar pasă tu de cere / La fiare rânduiele!.. / Oricine au dorit să intre-n aşa post, / Nevrednic, defăimat de către toți au fost / Şi parcă înadins / Asupra ursului majorita s-au strâns. / Toți l-au heretisit, / Iar el au mulțumit, / Ba încă la cei mari și labele au lins. / Dar răul în priseci curând s-au dezvelit; / Căci ursul, cum au mers la tact, s-au apucat / De curățit, de retezat / Și, drept, oricare stup în labă-i au intrat / L-au scos de tot curat, / Iar mierea la bârlog mergea necontenit, / Pân' ce la sfat sau dat de știre / Și s-au orânduit / La fața locului pe forme deslușire. / Au mers, au cercetat, au scris, au lămurit, / Dar mierea n-au înapoit ; / Iar ursul de pe loc / S-a și trimis surghiun pe iarnă la bârlog. / El în singurătate / Își suge labele mult pline de păcate. / Și, ca un călător pe mare, / Așteaptă vântul cel de cale. / Nici nu mai zic nimică: / De urşi mi-i tare frică. ${ }^{6}$

K) Dacă, în viața privată, dezbinarea din micile rețele familiale, de prieteni sau colegiale, este indezirabilă, având în vedere consecințele, uneori dramatice, pe care le produce în plan personal sau în destinul unor ființe nevinovate (de regulă, copiii), ei bine, dezbinarea din cadrul instituțiilor statale ce funcționează pe bază de organicitate și deseori prin altruism social, dizolvarea lor din motive egotice, din interese meschine (iar, în acest al doilea caz, totdeauna interesele sunt meschine...), este un fenomen de-a dreptul catastrofal, cu consecințe deseori incalculabile, mergând până la disoluția autorităţii statale sau chiar la pulverizarea, aneantizarea acestuia... Cele mai grave infracțiuni sunt legate, în codurile penale moderne, de aceste iresponsabile atitudini de "privatizare" (de regulă, în siajul tiraniei), a funcției publice... Divide et impera ("Dezbină și stăpânește"), formulă binecunoscută în strategiile politico-militare, reamintită cu spirit doct de Nicolo Machiavelli,

${ }^{66}$ Al. Donici, op.cit., p. 79. 
în celebra-i capodoperă Principele însoțește istoria omenirii de câteva mii de ani..., cel puțin de la Filip al II-lea al Macedoniei (382-336 ante Cristum) ${ }^{67}$.

Împărțeala: Având tovărăşie / La o negustorie, / Câțiva prieteni pe viață / Au câștigat mulțime de bani gheață. / Şi adunându-se la casa lor obștească / S-au apucat folosul sămpărțească. / (Dar sunt cam rare împărțele / Fără gâlceve sau smintele.) / SSi-ai mei prieteni buni, câș̦tigul împărțind, / S-au întărtat la sfadă. / Când, iată! deodată, / Aud strigând: / - Săriți! săriți! foc! casa arde! / - Lăsați şi ne vom socoti pe urmă; / Dar trebuie să ştiți că mie mi se cade / Din cea de față sumă / O mie încă și mai bine, / Au zis dintre tovarăși unul. / - Iar mie în tot bunul / Vro două mi se vine, / Le zise lor un alt. / - Aidem însă! - Ba stați, / Și dreaptă partea mea îmi dați, / Strigară celalalt. / - Da pentru ce? Și cum?... / Sfădindu-se așa, prietenii văd fum / Cu pălălaie-n casă, / Și neputând să iasă, / Au ars ei toți, cu bani, cu tot. / Aici a zice pot: / Că la un rău obștesc, când cere trebuința / Ca să-l întâmpinăm puind unit silința; / Adeseori pierim obștește, / Când fieștecare / Strigând cu gură mare, / La interesul său în parte ațintește. ${ }^{68}$

L) Ce poate determina dezavuarea legii celei mai clare, înfrângerea moralei comune și a convențiilor sociale neechivoce? - Eternul exemplu sau, mai bine, contra-exemplu personal... Slăbiciunile morale ale celor ce sunt chemați să vegheze asupra respectării lor ca veritabili gardieni ai normelor. Or, tocmai aceștia transgrezează uneori legile şi morala pentru a face loc abuzului în nume persoanal, familial, de grup (infracțional sau nu) sau de grup legitim, dar convertit, prin aceste silnicii, prin aceste violări de norme, prin aceste "hatâruri", în veritabil grup infracțional. Iar "Justiția", cu proverbiala-i banderolă neagră de pe ochi, îi ține închiși, deși, în societate, pentru asigurarea respectării nediferențiate a legii, ar trebui să aibă înfățișare

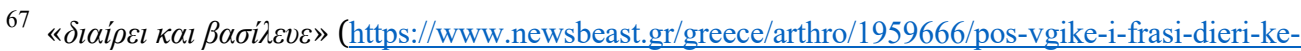
vasileve, 24.I.2018).

${ }^{68}$ Al. Donici, op.cit., pp. 90-92.
} 
mai degrabă de Proteus, cel cu o sută de perechi de ochi..., simbol al cenzorului roman, veghetorul moravurilor din Roma clasică... Indulgența horațiană ${ }^{69}$, simbolizată de cecitatea indusă (vecină cu indiferența sau neglijența în serviciu) naște altă indulgență și societatea va cunoaște un cerc vicios în care toți devin "rude" captive, precum în alegoria lui Donici...

Vărul primare: Sub lavițe-n cămară / Toți şoarecii de frunte făcuse-odinioară / Sfat mare între ei, / La care hotărâse cu multă scumpătate, / Ca în a lor cetate / Să nu se-ngăduiască nici unul din acei / Ce nu vor avea coadă; pe un temei puternic, / Că șoarecul nevrednic / Să-şi cruțe coada sa, / La întâmplări mai grele / Cetatea va lăsa / În prada mâței rele. / Se vede că ei coada o au semn de trufie, / Sau merit osebit; / Precum la noi fu barba cu titlu de cinstit. / Oricum pricina fie, / A șoarecilor act / Sub lavițe la tact / S-au pus în împlinire. / La următoarea însă obștească întrunire, / Un șoarec fără coadă cu cei de frunte sta / Și pricini cerceta. / Alt şoricel cu laba vecinul îşi ghiontește / Şoptindu-i: "Nu vezi, frate, ce rău ni se gătește! / Cum poate fi primit / Un șoarec prihănit / În astă preacinstită de cozi lungi adunare? / Şi tu, bătrân ales, / Păzești tăcere mare". / - Păzesc tăcere, dragă, căci el mi-i văr primare./ Destul, am înțeles. / Nici în vizunii, oare, / Hatârul lege n-are? ${ }^{70}$

M) Justiția, spune unul dintre înțelepții Antichității clasice, poetul latin Publius Ovidius Naso ${ }^{71}$, a fost cretă pentru ca legile-i să protejeze societatea de "cei puternici", pentru ca aceștia din urmă "să nu poată totul". Este o explicație diferită de aceea celebră a lui Mihai Eminescu: Spuneţi-mi ce-i dreptatea? - Cei tari se îngrădiră / Cu-averea şi mărirea în cercul lor de legi, din cunoscuta poezie "Împărat şi proletar". Ambii gânditori au dreptate,

${ }^{69}$ Quintus Horatius Flaccus, Satirae, 1, 3, 74 sq.: Aequum est / Peccatis veniam poscentem reddere rursus ("Este just ca cel care cere îngăduința pentru greșelile sale s-o acorde, la rândul său”), apud Th. Simenschy, op.cit., pp. 329-330.

${ }^{70}$ Al. Donici, op.cit., pp. 118-119.

${ }^{71}$ Publius Ovidius Naso, Fasti: Inde datae leges, ne fortior, ne firmior omnia possit (Faste: "Și de aceea au fost create legile, pentru ca cel puternic să nu poată totul"...). 
fără ca acest lucru să fie un paradox. Este motivul pentru care, exempli gratia, furtul nu este prevăzut cu un prag valoric minimal... Dar, ceea ce diferențiază societățile civilizate de altele constă în moravurile judiciare. Judecătorii înțelepți, care joacă și un rol profilactic în societățile lor și, firește, unul didactic, aproape de idealul paideei sociale a adulților, aplică pedepse draconice celor "mari” și îi înțeleg cu mai multă toleranță pe cei "mici”...

Jderul și cacomul (hermina, n.m.): - Da' bună ziua, nene! Îmi pare curios / Ca să te văz astăzi în piele și voios; / Ieri am privit, eu singur, ciudata vânătoare / După cacomi: trei oameni din ochi te urmăreau / Și te-ndreptau mereu / Spre mlaștina cea mare; / Apoi am văzut încă, cum toți la ea au stat / Și te-au înconjurat. / Atunci... și eu, vezi bine, / Temându-mă de mine, / În scorbur-am intrat / Și nu știu ce s-a mai urmat. / Ian spune-mi, drag vecine, / Cum ai scăpat din lăbi de om? - Întrebă jderul pe cacom. / - Cum am scăpat? răspunse cacomul moderat, / Curat ca prin minune, / Dar trebuie a-ți spune / Un lucru vederat: / Că omul din natură are / Plecări destul de bune. / Tu ai văzut cu ochii cum m-au înconjurat / La mlaștina cea mare / Și știi că eu mai bine mă dau prins / Decât să fiu de glod atins. / Ei bine! / Văz că-un om s-apropie de mine, / Îmi pune pe cap mâna și zice la ceilalți: / "Emblema curăției, el trebui să trăiască / Ca în integritate pe om să pilduiască! / Aideți mai bine, frați, / Să prindem pe murdari, / Pe jderi, pe vulpi, pe angării mai mari. / Ce port virtuți pe gură, / Dar dau prin glod și fură. ${ }^{72}$

N) Infracțiunile contra mediului, epuizarea resurselor naturale, a resurselor de orice gen, pentru o falacioasă îmbogățire rapidă, cu consecințe dintre cele mai funeste ca și cum ne-am afla într-un război inter-generațional, emasculând progeniturile noastre printr-o "rezervă succesorală" putredă, săracă, sau cu totul absentă. Este vorba, aici, de crime grave îndreptate împotriva umanităţii (nu doar viitoare, ci şi prezente), de crime îndreptate şi împotriva memoriei umanității, viitorimea putând să-i judece pe strămoşii

${ }^{72}$ Alecu Donici, op.cit. (Fabule şi satire), pp. 158-159. 
noștri stoici și frumos articulați moralicește cu noi, cei abuzivi, nesățioşi, extrem de lacomi şi de urât construiți sufleteşte, cu noi, materialiștii dezumanizați, dominați de propensiunile noastre infracțional-hapsâne. Povestea tristă a avidității fără margini... devenim tot mai săraci înecați în opulențe... ${ }^{73}$

Râmătorul: Un râmător din fire născut nesăţios / Aflând destulă ghindă sub un stejar stufos / A ros cât a putut / Şi-apoi la rădăcină să râme-a început. / Tu surpi copacul, zise o pasăre zburând. / Ce-mi pasă, râmătorul răspunse grohăind, / El fie ori nu fie, nici vreau să mai gândesc: / Eu caut numai ghindă, la care lăcomesc, / Fiindcă ea mă-ngraşă. - Urâte râmător / Şi nemulțumitor! / I-a zis atunci stejarul, ridică-ți surla-n sus/ Şi vezi: că-această ghindă eu, eu o am produs. / Nerozii în orbire ştiințele urăsc, / Când ei din a lor roduri încă se folosesc. 74

O) Este posibil a încheia această parte aplicativă a studiului nostru, una în care am selectat fabulele cu subiect juridico-moral din ansamblul fabulisticii sale, fără a-i ilustra capodopera, cea mai cunoscută, pe aceea care a devenit emblema argumentației unioniștilor (devenită, în 1863, deviză princiară pe stema Principatelor Unite, TOȚI ÎN UNU, ce ne amintește de deviza muschetarilor şi a N.A.T.O.75, dar şi de rădăcinile-i istorice care coboară până la principiul subsidiarității, la Johannes Althusius, la Sf. Augustin şi la Aristotel) $7^{76}$ față de înşelătoarele aserțiuni sterile, inutile, perdante şi, finalmente, ridicole ale separatiştilor. Desigur, nu mă pot referi decât la "Racul, broasca și știuca"?. Răspunsul nu poate fi decât negativ, deși,

\footnotetext{
${ }^{73}$ Horatius, Odes, 3, 16, 28: Magnas inter opes inops ("Sărac, în mijlocul unor bogății mari”), apud Th. Simenschy, op.cit., p. 52.

${ }^{74}$ Al. Donici, op.cit., p. 174.

${ }^{75}$ Toți pentru unul, unul pentru toți...

${ }^{76}$ Valerius M. Ciucă, Euronomosofia, Vol. I. Prolegomene la o operă în eșafodaj, Editura Fundației Academice AXIS, Iași, 2012, pp. 116-118.
} 
în cazul acesteia, prevalează mai mult spiritul politico-moral decât cel juridic, un spirit dominat de Viribus unitis al lui Alexandru Papiu Ilarian77, fratele și congenerul de peste Carpați ai celor mai înainte evocați, un spirit dominant, cu toate conotațiile preferate în anii de glorie ai mișcărilor paşoptiste şi unioniste din Țările Române. Este, cred, un fericit Memento(!). Pentru Centenar...

"Racul, broasca și ştiuca: Racul, broasca şi o știucă / Într-o zi s-au apucat / De pe mal în iaz s-aducă / Un sac cu grâu încărcat. / Și la el toți se înhamă : / Trag, întind, dar iau de samă / Că sacul stă neclintit, / Căci se trăgea neunit. / Racul înapoi se da, / Broasca tot în sus sălta, / Știuca foarte se izbea / Și nimic nu isprăvea. / Nu ştiu cine-i vinovat ; / Însă, pe cât am aflat, / Sacul în iaz nu s-au tras, / Ci tot pe loc au rămas. / Aşa-i şi la omenire, / Când în obşte nui unire : / Nici o treabă nu se face / Cu izbândă și cu pace.”78

\section{$*$}

Iași, 24 Ianuarie, 2018

\footnotetext{
77 Alexandru Papiu Ilarian, Istoria românilor di Dacia Superioară, Vol. I, Istoria românilor din Dacia Superioară până în anul 1848 exclusiv, Ediție îngrijită, prefață, bibliografii, glosar și notă asupra ediției de Serafim Duicu, Cu un cuvânt înainte de Acad. Ștefan Pascu, Casa de Editură Mureș, Târgu-Mureș, 1996, p. 175: ”(...) și care sunt acei români ca să-i deie istoria la judecata generațiunilor viitoare; mai sufer a se înșela de străini ca să piardă timpul în nelucrare, au și certându-se între sine asupra unor lucruri foarte mărunte și prea de nimic și să părăsească causa națiunei întregi; au doară acum lucră pentru cultura și fericirea, pentru viața presentă și pentru cea viitoare a toată gentea "VIRIBUS UNITIS”?.” Inchei cu un semn de gratitudine pe care-l exprim față de domnul Profesor dr. Nicolae Ploeșteanu, fiul regretatului istoric, profeseor dr. Grigore Ploeșteanu, îngrijitorul ediției din 2005 a volumelor II-III ale acestui monument cărturăresc născut în inima spațiului românesc prin spiritul profund și laborios al luminatei minți pașoptiste, Al. Papiu Ilarian, o gratitudine manifestă faţă de actul spontan de-a-mi fi dăruit cele trei tomuri în sobrul sediu al universității eponime din Târgu-Mureș.

${ }^{78}$ Alecu Donici, op.cit., p. 64.
} 